\title{
WARS OF MEMORY
}

Konstanty Gebert

Periodista

konstanty.gebert@g.pl

\begin{abstract}
REsUMEN
El artículo analiza los puntos de vistas conflictivos de judios y polacos sobre la Shoah y el impacto de la "Marcha por la Vida" desde esas perspectivas. Se comparan los amargos debates históricos entre polacos y los judios sobre las relaciones polaco-judías con las polémicas internas en Polonia después de la gucrra; describe las erróneas percepciones mutuas comprometidas en ellas y postula una intensificación del debate.

Palabras Clave: Polonia, Shoah (Holocausto), "Marcha por la vida".
\end{abstract}

\begin{abstract}
The article analyzes conflicting Polish and Jewish perspectives on the Shoah, and the impact of the March of the Living on these perspectives. It compares the bitter historical debates between Poles and Jews on Polish-Jewish relations to internal Polish polemics on post-war Polish history, describes mutual misperceptions involved, and postulates an intensification of the debate
\end{abstract}

KEY Words: Poland, Shoah, March of the Living.

Late in April each year, thousands of young Israeli and Diaspora Jews come to Auschwitz for the March of the Living. Surrounded by security men, they cover in silence the 6 kilometers dividing the main camp from the remains of the gas chambers at Birkenau. The event roughly coincides both with the anniversary of Israel's independence, and with that of the Warsaw Ghetto Uprising. It is a painful reminder of the background against which -and somehow also thanks to which, however odious it may sound-Israel came into being. Irrespective of all the political ends that have been attempted or gained through the use made of the March and of those two anniversaries, one point must be borne in mind both by Jews and non-Jews: Israel was brought into being because Europeans in Europe had exterminated the Jewish nation. The international consent to the creation of a Jewish state was primarily dictated by a desire to seek expiation for this. The necessity of getting rid of the survivors of the Shoah had also played a role: they should not provoke further qualms of conscience by their presence. They must not constitute too emphatic a reminder that Germans were only the executors of the work done by the whole continent. All that 
must be remembered when thousands of young Jews, bearing Israeli banners -quite mindless of Poland they are passing through-are marching from Auschwitz to Birkenau.

It is true that it was the Germans who were the architects and executors of the Shoah. But they were assisted in their work by so many Frenchmen and Poles, Lithuanians and Croats, Italians and Hungarians. The heroic and exceptional acts of assistance to Jews, by individuals and groups of all nations, primarily Poles but including even some Germans, cannot change the entire picture. Europe handed Jews over to Germans for extermination. For a Jew who was apprehended by a French gendarme and transported to a German death camp, and who miraculously escaped from the transport, only to be denounced by a Polish peasant to an Ukrainian policeman, it must have seemed only remotely relevant that those nations were also waging a life-or-death war against one another, apart from being busy persecuting Jews. As far as the Jewish issue was concerned, all those nations were perfectly like-minded.

That experience -the mixture of fear, loneliness, alienation and icy hatred-cannot be possibly understood by anyone who was not then being hunted down. However, the next generations of Jews in Europe can still imagine it better than others. We have inherited sharper senses of sight and hearing -and no illusions. We record every Jude raus! in a street of Warsaw, every Neo-Nazi demonstration in Germany, or vote for Le Pen in France. We realize that our local citizenships may not last long. And that is one of the reasons why Israel is and will remain close to our hearts. Only there do we have an unchangeable, indestructible and unquestionable right to live.

Young Israelis do not have such an education behind them. The March of the Living is their first trip to the heart of darkness. To a place which, no less than gothic cathedrals and university reading rooms, expresses the essence of Europe? And when, once there, they hear-and they occasionally do-cat-calls and curses, and when their coaches are hit with stones, they know that "there and then" was very much the same as "here and now" is. They know that Europe, homicidal Europe, is once more unveiling its true face.

And such is the intended message of the March. Its organizers want the participants to become convinced that Poland, or Europe, means death, while Israel is resurrection. They still want -just like classical Zionists did- to "negate the Diaspora," with just one exception -that of the American one, successful on a scale unseen since the Golden Age of Spain. This negation of the Diaspora, and the hostility towards Jews who choose to live in Europe is a blow against us, European Jews, and is offensive to us. But we know that the organizers of the March are mistaken in only one respect -they seem to believe that nothing has changed here, and never will. We, on the other hand, ground our relative optimism in a conviction that this does not need to be so -even if we do realize that it might. We also know that the organizers would become less certain of the exceptionality of the American Diaspora, had they led their March through the streets of, say, Harlem NY. It is always risky to walk rich kids through a poor land.

It is especially risky when they are taught to slight and hold that land in contempt. True, despicable paragraphs expressing hatred towards Poles "for their participation in the atrocities" have in 2000 been removed from the brochures distributed to participants. This is an achievement of all those who publicly condemned such views -including Polish Jews. The success is at 
the same time a token of something much larger: the March itself is changing. In 1996, for the first time, a young Polish Jew, Ruta Śpiewak, made a speech at the ceremony opening the March. Hitherto we, Polish Jews, had been treated suspiciously -as fools or renegades. For how else can the fact that a Jew stays on in such a place be accounted for?

I am not going to try and explain it. I will only say that the majority of people I love live here. And that is the reason that outweighs everything else.

In 1998, for the first time, the organizers of the March have agreed to allow a group of non-Jewish youth to take part in the March. I am not sure if the Polish side fully realizes the significance of this gesture. The pain that fills us when we think about Auschwitz, when we feel Auschwitz with every fiber of our souls, while walking from Auschwitz to Birkenau, across the land of ashes of our whole nation, is so excruciating that nothing can ever alleviate it. This March, though public, is the most intimate of all Jewish undertakings. And since 1998 non-Jews have been allowed to share in this intimacy. This was possible simply because it has been finally understood that further refusal would mean rejecting the pain of the non-Jews, slighting their suffering and their need to express solidarity.

And yet it must be brutally said that that does not put an end to the differences between us. The Polish nation -thank God, for not its allies- was not exterminated. It still exists. It remains part of the continent which, during its long civil war, lasting with some intervals half a century, has always found an occasion to murder Jews. Naturally there is no such thing as collective responsibility for actions, but for history, there is. And the history of Europe is Christian. Such a declaration must provoke a protest when treated normatively, but descriptively it is true. And the symbol of this Christian history of Europe is the cross. The one that towers above the camp walls. The one that has been the cause of yet another terribly painful and terribly dangerous Auschwitz conflict.

In the experience of European Jews, Christianity had laid the ground for the Shoah. To us the cross in Auschwitz is a symbol of the perpetrators and not of the victims. Raising it in the cemetery of the Jewish victims of Christian Europe insults us. These words must be treated quite literally. I think that Christians are as much power to convince Jews that the cross is in fact a symbol of love, as -mutatis mutandis- Jews have of convincing Palestinians that the Shield of David is a sign of the helpless and persecuted. That must be understood by Christians. And what about Jews?

We must understand two things -and neither of them will be easy. First of all, the cross was not put up against us. And second of all, it was raised for reasons relevant for Christians.

For the majority of Jews, whatever happens at Auschwitz or Birkenau concerns them and is addressed to them. The Polish non- Jewish martyrdom connected with that place is hardly even known to them. This was experienced on manifold occasions by revered opposition figure and former foreign minister Władyslaw Bartoszewski: when he would say abroad that he had been a prisoner of Auschwitz, he often heard in reply, "Oh, I did not know that you are Jewish". And 
he is not: Auschwitz had also seen the suffering of untold scores of Gentiles. Over a hundred thousand were murdered there, alongside over one million Jews.

For Jews, Auschwitz as a place of the Shoah is so powerful a symbol, that it leaves no space for other symbols, messages or values. We must understand that for Poles Auschwitz is a symbol of their own martyrdom. The fact that Poles overall suffered so much less than Jews has little bearing on the subject. It is pointless to discuss the feelings of either side. That cross insults us but it was not erected for that purpose. It was raised to commemorate a place where some European Christians murdered some other European Christians - Catholic Poles executed by Germans. For Christians the cross is an appropriate means of commemorating such places. However, it is not appropriate at a Jewish cemetery.

How to settle this dispute? I have no idea. Maybe the right solution was put forward by a woman who, during a live radio debate I participated in, suggested that the Jewish ashes could be transported to Israel. She added that Christians would willingly raise the funds to cover the costs of the whole project. I listened to her with rapt attention, hoping to detect in her voice a hatred that would account for the unbelievable vileness of her proposition. But I failed. My radio interlocutor was convinced that her suggestion was nothing but an expression of her best intentions of finding a compromise.

The problem is that this cannot be done. Our ashes, burnt in the fire of the European crematoria, can never be removed from the earth, water and air of Europe. We shall stay on here, even though sometimes we both - they and we - think that it might be better if we could part. We shall stay on, just like - mutatis mutandis - the empty tomb of Jesus of Nazareth will stay in the heart of Jerusalem, and although Jews would rather not see crosses set in their land, nobody in Jerusalem would think of removing them. But in Auschwitz - in the place where not one but a million Jews perished - no crosses should be present.

There is not good solution to this problem, but there exists a precedent. The Auschwitz death cell of Father Maksymilian Kolbe, a Polish priest martyred by the Germans and now a saint of the Catholic church, has been converted into a chapel - with crosses. They do not insult anybody, for the only visitors there are those who do want to see crosses in this place. I am not disturbed in my prayers by the knowledge of their presence. What disturbs me in my prayers in Auschwitz is the awareness of the place I am at.

A cross - a smaller one, and not towering over the camp - would constitute on Auschwitz soil an insult only to those who would wish to be insulted. To those who would search for it only to strengthen their hostility and pain. I empathize with their feelings. I also understand the feelings of those who resent the presence of the crosses on the church tower in Birkenau, perfectly visible from the Birkenau crematorium. But the church, unlike the Auschwitz cross, does not stand on the territory of the camp. Its crosses are not eight meters tall. There is a limit to what we can realistically demand in the name of our pain.

So we must talk. We must negotiate terms and conditions; compare the harm brought about by political confrontation and the costs of concession. Probably it is pointless to hope that the 
obscenity of the whole conflict and the impropriety of the very presence of the cross in such a place will finally be recognized as being obvious. The suggestion of transporting all the ashes as a means of resolving the problem proves to what extent -more than half a century after the crematoria cooled down-Auschwitz still has the power of poisoning human souls.

And that is our failure. That of both the Jews and of Europe. For it transpires that Auschwitz -a place which everyone should approach with paralyzing terror in their hearts, whose gates should be entered at the peril of one's soul, where no one would dare drag in their own symbol or emblem- that the place has been tamed and made familiar. Through the combination of massive tourism to the Disneyland of horror and of political games played over that place, the terror emanating from Auschwitz has been muffled and reduced.

And we should never cease to feel it. It is precisely the lack of terror that should evoke terror, for we know that it all was and remains possible. Only terror can raise a barrier, if uncertain and fragile, against the comeback of the nightmare. Not necessarily against Jews: there are after all, Gypsies, Bosnians and immigrants, to name but a few real and potential other victims. When Europeans are not terrified of themselves, everyone else should be.

Each year, the March of the Living exits through the main gate of the camp and turns left towards Birkenau; the participants' backs turned to the cross guarded by police units, especially alert on that day. It walks straight towards the human ash heaps dumped at Birkenau. Then all weep together and candles are lighted.

And then the visitors will leave and fly away, to rest and recuperate at home. This the Jews and non-Jews who live in the place they had come to visit cannot do. They go on living in the land of ashes -even if at times it seems that this is the only bond they have in common, while so much else drives them apart.

Memory especially separates them. Yet memory is not chiseled in stone, and in present-day Poland a war over memory is well under way. It is a war over memory, not history: it concerns the place of significant events of the recent past in peoples' minds, and not so much their depiction in professional historiography. The time span is defined quite precisely: the problem concerns salient developments of the last sixty years of the past century, and the role played in them by living people, their grandparents and parents. The events that matter are those whose assessment directly impacts the identity of present-day Poles, on which the answer to the question "who are we?" depends. Two fronts in this war are especially active: the attitude towards Communist Poland -the Polish People's Republic [PRL], and the assessment of Polish-Jewish relations.

And this is a war, not just a debate or a controversy. Factual arguments or findings of researchers count only to some limited extent. The decisive factors here are the political and moral results of commonly held opinions. In other words, it is not facts that determine the judgment, but the reverse: it is the judgments formed a priori that dictate the readiness to consider or ignore facts. That is why any discussion of these matters so much resembles a dialogue of the deaf. This is not new to Poland, nor is it a Polish peculiarity: France occasionally argues about Revolution, Spain continues to be divided by Franco's heritage, while on the other hand in Russia the debate 
over Stalinism continues in intelligentsia circles only. Poles in the past had also fought over assessments of the 19th-century uprisings, the causes of the September 1939 defeat, and the outbreak of the Warsaw Uprising, to name just the major few. All those controversies, even the last one, belong to the past now: as to the facts a rough historiographic consensus has been reached, largely based not on a victory of either party, but on the adoption of a middle position which incorporates arguments of both. This was made possible more by generational change than by any historical break-throughs. Such will also probably be in the future the fate of the currently waged wars, but today they cause a major divide that runs across Polish society.

While the war over Communist Poland (was it only a Soviet puppet regime? Did Polish Communists have any consideration for Polish interests?) remains an internal, Polish affair, in the war over Polish-Jewish relations, the situation is different. The conflict crosses borders and to a large extent concerns not only the relations between Poles and Jews, but also within the two nations. Outside of Poland and of Polish and Jewish communities abroad, there are few supporters of two extreme views, which are often passionately being expressed. According to the first view, Jews in Poland constituted a destructive anti-state and anti-national force, which remained in constant conflict with Polishness and Catholicism. Besides, Jews are to blame for capitalist exploitation in the 2nd (interwar) and 3rd (present-day) Polish Republics, for Communist anarchy before the war, as well as the Communist dictatorship after it.

According to the followers of this view, Poland always had to defend itself against Jews, and did so, if ineffectually, while fully abiding by civilized principles. Before the war, they maintain, the Poles had to resist Jewish attempts at taking over the Polish economy and subverting the Polish state, and during the war defend themselves against mass collaboration of Jews with the Soviet occupant. At the same time they were heroically defending Jews against the German occupant, at the cost of dozens of thousands of Polish lives, even though Jews had supported Germany in its war with Poland. After the war Poland once more had to defend itself, this time against a Moscow-imposed Jewish-supported dictatorship, and simultaneously fight for its good name against Jews and their allies, who defamed her the world over. In this self-defense some lamentable misdeeds took place, as they would during a war, yet they were nothing compared to the infinite wrongs committed by Jews. Meanwhile, the Catholic Church remains Poland's lone staunch ally, and this is why Jews slander it too, ascribing to it a non-existent anti- Semitism.

Among Jews living abroad an opposite view prevails, according to which Poles are a nation marked by an inborn anti-Semitism, additionally strengthened by the intrinsically anti-Semitic Catholic Church. The history of Jews in Poland is an endless stream of harm and persecution, which logically had led to the Germans choosing it as the site for their concentration camps. Poles and Germans were united by their common hatred of Jews, advocates of this view maintain, overriding even the conflict that divided the two nations during the war: Poles were willing accomplices in the Shoah. The rare cases when individual Poles, in opposition to their nation, extended kindness to Jews or even came to their help, only confirm the generally prevailing rule. Jews could seek protection from this irrational, irremovable Polish only at the hands of a powerful state authority, be it Soviet or native Communist. That authority, however, acted in there favor only when it found it necessary and eventually turned against the Jews. Throughout, discrimination, pogroms and massacres were the norm, and came to an end only when there were no Jews 
left to persecute -yet even in their absence, anti-Semitism in Poland keeps on thriving, defaming their memory and hindering any endeavors made by a handful of noble Poles to at least partly make amends to Jews for the evil done to them.

In the war over the PRL, the parties -those who totally condemn the regime and those who seek excuses for it- share a common national identity, geography and history. They continue to live together, side by side, and they can refer to a living memory of the events that have divided them. Moreover, each side knows that the other one will not disappear, and that they will have to continue to co-exist together in Poland - which means that ultimately a compromise would be realistic. One may condemn Communist Poland, while sharing with its advocates a critical view of the 3rd Polish Republic. One may idealize Communist Poland and yet honor those who fought against it. It must be reminded here that we are speaking here only about collective consciousness, and not factual, historical arguments, where the judgments must stem from facts, and not the reverse.

In the Polish-Jewish war over memory space for maneuver is drastically restricted. The parties no longer share a common geography, and it is doubtful whether they have ever shared a common history, as both sides in the war over Communist Poland do: e.g. the Soviet invasion on September 19, 1939, objectively stands for something entirely different to the majority of Jews than to most Poles. What is more, the differences in opinion to a large extent correspond to the ethnic identity of those who hold them: although not many Poles hold the first of the two extreme views, and only few Jews hold the opposite one, it would be difficult to find a Jew who would be of the first opinion, or a Pole of the other.

Geography -no longer shared- does not extort a compromise, while history, which was never common, does not leave any space for it. In this situation, a Pole, criticizing the first extreme stance, can be accused of legitimizing the opposite one -even if this is not the case at all. The same holds true for a Jew if he refuses to accept the other approach. The majority on both sides, which probably holds these two approaches to be equally false, still has to suffer the adverse consequences of their being so passionately advocated.

Last of all, the burden of criticism is incomparable in the two cases. In the war over Communist Poland, the opposing parties accuse one another of wrong political decisions, self-interest, or -worst come to worst- treason. But the first of the two extreme positions in the Polish -Jewish controversy mandates accusing Jews of an elemental hatred and total ingratitude towards Poland, of participation in the violation of its freedom and in crimes against hundreds of thousands of its citizens. On the other hand, the other extreme position is based on the assumption that Poles collaborated in the preparation and realization of the most horrible genocidal undertaking in human history, as well as in the ultimate distortion of facts concerning it. The former view inspires the image of a Jewish officer working for the Communist Security Police and torturing Polish patriots, while the other one -of a Polish peasant denouncing some Jews in their hiding-place to Germans for a bottle of vodka. The emotional strain the conflict generates is so great that rational judgment is hardly possible. And even though it is doubtless that the suffering of Jews -which in most cases Poles cannot be blamed for- is simply much greater than the suffering experienced 
by Poles -and in which Jews participated to a much lesser degree- human memory is not ruled by comparative analysis in such cases.

It is not ruled by it -until one reaches for historical sources. Among serious historians there is no fundamental controversy over facts any more. It is a well-known fact that the 2 nd Republic of Poland was not a land of growing anti-Semitism, which was, however, not the sole attitude toward Jews, nor was it driven by genocidal intent. We know that Germans built their concentration camps in Poland due to the fact that the majority of the Jews to be killed lived there, and not because of the attitude Poles had towards Jews - which was quite irrelevant to Germans. We know that the shmaltzovniks outnumbered the rescuers, but that among the Righteous of the $\mathrm{Na}$ tions, Poles constitute the largest group. That Poles are to blame for Jedwabne, but that occupied Poland was not one great Jedwabne. That Jews constituted a large group among Security officers, but that they executed Communist and not national policy. That Jewish organizations supported the dictatorship imposed on Poland - but that in the face of the post-war pogroms they could not possibly have taken a different stance (even if they had wished to- but would they had?). We know that anti-Semitism is still present in Poland, but that the debate over Jedwabne has not been equaled in its honesty and depth in any other country occupied by Germans in World War Il. To put it briefly, we know that both extreme opinions expressed in the two wars - over Communist Poland and Polish - Jewish relations- are simply untrue.

The problem, however, is that -unlike the case of the assessment of the post-war half-century- this acknowledgment has almost no chance of becoming common opinion. Hardly anyone reads serious popular historical literature. Poles and Jews live separately today, they know little of one another and have much more serious troubles at hand than trying to reinterpret their views, so far mostly adopted uncritically and confirmed by family historical reports, as well as information sporadically coming from the other side.

The descendants of the Polish Jews living in New York or Haifa know about Poland not more than that before the war their grandfather was beaten by student activists, because he refused to sit in the bench ghetto at University; that later on his cousin was blackmailed by schmalzowniks and that her fiance was killed already after the war, when he appeared at his family home. Then came March 1968, priest Jankowski and the photographs of graffiti of Stars of David on the gallows, taken by their son during a trip to Poland. Enough.

But "enough" can also be said when a Pole remembers his family history with a grandfather indebted to a Jewish usurer; triumphal arches raised by some Jews to welcome the invading Red Army in September 1939, Communist leader Jakub Berman supervising the dread Communist secret police, the fifty years it took after the unveiling of the monument to the heroes of the Warsaw ghetto uprising of 1943 for one commemorating the Warsaw uprising of 1944, and foreign press articles about the Polish concentration camps. We shall never understand the degree of malevolence in the mutual relations if we do not accept the fact that historically groundless or morally outrageous opinions can be expressed by decent people, responding only to their own historical memory, and to the equally groundless opinions expressed by the other side. In fact it is quite astonishing that in spite of such encumbrance, any rational conversation is possible any more at all. 
And it is indeed. More in Poland than outside of it, for to descendants of Polish Jews abroad, Polish history is foreign history. Their own history is connected with a country which, for the first generation of emigrants, was initially only a dwelling place, but for their offspring has already became their native land. For American Jews, for instance, the civil rights movement, and for Israelis -and the Diaspora- the war for independence, are incomparably more relevant than what once happened in Przytyk, Jedwabne or Warsaw. Yet for us in Poland, for Poles and Jews, the order of priorities is different. That history is ours. And that is why we shall continue to argue about it.

We shall argue -for today the issue is even more contentious than in the past. But in Poland that war is at least not solely a Polish-Jewish one only: it is a general war over Polish memory. Those in Poland who, after the groundbreaking book by Jan Gross, led to the disclosure of the whole truth about Jedwabne, were not interested in if and what Jews might think about it. Their only concern was that the shame of crime -for which the individuals who committed it, as well as their ideological supporters, were liable-- not be made even more grave by the shame of falsehood, for which all of us would have been liable. And this they succeeded in doing, which we must bear in mind with gratitude. Those, on the other hand, who carry on polemics against the Jewish black legend of Poland are not worried that it may be applauded and exploited on the other side. They know that the two legends feed on each other, and a fight with one means a fight with both of them.

The Talmud teaches us that in an argument undertaken "in the Name of Heaven"-and so with due respect towards the truth and one's opponent- both opposing positions are "the voice of the Living God," even if one of them should ultimately prove to be false. Both Poles and Jews are in desperate need of such arguments. 